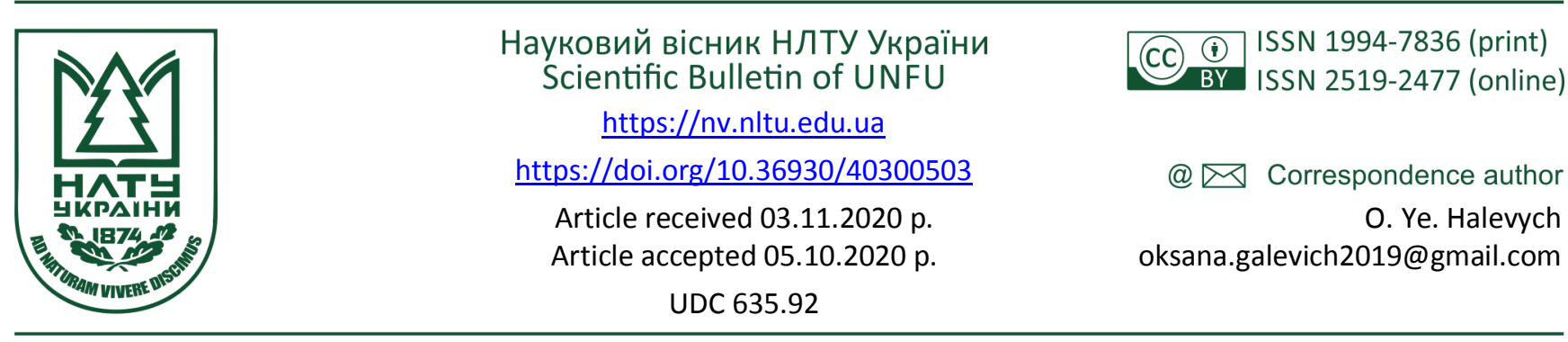

О. Є. Галевич, М. І. Сорока

Національний лісотехнічний університет Украйни, м. Львів, Украӥна

\title{
АНАЛІЗ СПОНТАННОЇ ФЛОРИ ПЛОСКИХ ЗЕЛЕНИХ ДАХІВ ЕКСТЕНСИВНОГО ТИПУ У МІСТІ ЛЬВОВІ
}

\begin{abstract}
У Львові досліджено 18 об'єктів з озелененими плоскими дахами екстенсивного типу, влаштованими на різних висотах та різних типах будівель. Проаналізовано сучасні методи та технології створення озеленених дахів та висвітлено основні напрями досліджень у цій галузі. Розглянуто основні принципи класифікації і типіфікації зелених дахів. Здійснено інвентаризацію видового складу культивованих і спонтанних видів рослин. Виокремлено групи зелених дахів за домінуючою біоморфою використаних видів: 3 перевагою сукулентів; газонні дахи; з участю ефіроносних рослин середземноморської флори; з використанням деревних рослин. Вперше у працях такого типу досліджено спонтанну ценофлору, яка супроводжує культурфітоценози зелених дахів. Встановлено, що вид озеленення істотно впливає на формування фітоценозу та визначає основні напрями агротехніки утримання насаджень екстенсивного даху. Виявлено тісну залежність між типом озеленення даху та видовим різноманіттям спонтанних рослин. Встановлено шляхи поширення діаспор занесених видів. Флористичний аналіз спонтанної ценофлори плоских зелених дахів показав, що вона сформована 59 видами, більшість 3 яких є рудеральними бур'янами із синтаксономічного класу MOLINIO-ARRHENATHERETEA. Другу за чисельністю групу складають сегетальні бур'яни із класу STELLARIETEA MEDIAE, що свідчить про високу агротехніку утримання рослинних композицій на дахах, де переважають спонтанні види першого етапу заростання оброблених земель. Серед виявлених видів бур'янів переважають стрижнекореневі полікарпічні анемохоричні гемікриптофіти, що характеризує спосіб їх занесення у рослинні композиції. Більшість із досліджених видів не були занесені із субстратом, а поселилися пізніше за допомогою поширення діаспор вітром. Чисельні групи складають види-барохори та антропохори, які заносяться у процесі виконання агротехнічних робіт. Оскільки занесені види рослин здійснюють негативний вплив на художньо-естетичну, декоративну та екологічну функції озеленених дахів, вперше доведено ефективність та доцільність запропонованих досліджень у цьому напрямі. Запропоновано скоригувати агротехнічні прийоми з метою утримання видового складу рослинних композицій, та впровадити ефективні екологічно безпечні заходи для запобігання забур'яненню рослинних композицій зелених дахів.
\end{abstract}

Ключові слова: системи озеленення покрівель; бур'яни; культивовані види; культивари.

\section{Вступ}

Зелені дахи, на яких створено композиції з рослин, висаджених у грунт чи композитний субстрат, - це сучасний напрям в озелененні, який до того ж має естетичні, екологічні та соціально-економічні переваги перед покрівлями із надсучасних матеріалів. Озеленені покрівлі значно зменшують температурні коливання у будівлі, покращують звукоізоляцію, створюють захист від пилу, зменшують кількість опадової води, яка стікає 3 даху, даючи змогу зекономити витрати енергоносіїв на опалення, кондиціонування та каналізування. Основною метою їх створення $\epsilon$ раціональне використання простору в середовищі, що швидко розбудовується, формування міських зелених дахів як функціонально обгрунтованого, зручного в експлуатації середовища. Розвиток садів на дахах у сучасній архітектурі Львова $\epsilon$ чинником істотного покращення просторового планування за рахунок використання поверхонь будівель. Вони, окрім утилітарної та естетичної ролі, виконують низку екологічних функцій та часто використовуються для забезпечення потреб міських мешканців, перетворюючись на цілі мікрорайони на дахах. Незважаючи на численні дослідження [13, 16, 19], які стосуються загальних характеристик, технологій створення, асортименту та агротехніки вирощування рослин, грунтовного вивчення спонтанної флори на зелених дахах не здійснювали. Саме тому у процесі досліджень ми зібрали матеріали, які стосуються способів розселення, екологічних та біологічних характеристик синантропних видів на зелених дахах та їх взаємозв'язків із культивованими видами рослин. Подібні дослідження повинні істотно вдосконалити агротехніку вирощування рослин на дахах та запобігати поселенню небажаних видів.

Об'єкт дослідження - спонтанна ценофлора плоских зелених дахів екстенсивного типу в умовах Львова.

Предмет дослідження - методи та засоби визначення видового складу спонтанної ценофлори на плоских зелених дахах, їх систематичної, біоморфологічної,

\section{Інформація про авторів:}

Галевич Оксана Євгеніївна, аспірант, кафедра ботаніки, деревинознавства та недеревних ресурсів лісу. Email: oksana.galevich2019@gmail.com

Сорока Мирослава Іванівна, д-р біол. наук, професор, кафедра ботаніки, деревинознавства та недеревних ресурсів лісу. Email: myroslava_soroka@yahoo.com; https://orcid.org/0000-0002-1037-6904

Цитування за ДСту: Галевич О. Є., Сорока М. І. Аналіз спонтанної флори плоских зелених дахів екстенсивного типу у місті Львові. Науковий вісник НЛТУ України. 2020, т. 30, № 5. С. 20-24.

Citation APA: Halevych, O. Ye., \& Soroka, M. I. (2020). Analysis of spontaneous flora on the flat green roofs of extensive type in Lviv city. Scientific Bulletin of UNFU, 30(5), 20-24. https://doi.org/10.36930/40300503 
синтаксономічної, діаспорнохорної структури та особливості формування.

Мета роботи - виявити видовий склад та здійснити флористичний аналіз спонтанної ценофлори на плоских зелених дахах екстенсивного типу в умовах Львова.

Для досягнення зазначеної мети визначено такі основні завдання дослідження:

- здійснити інвентаризацію видового складу культивованих і спонтанних видів рослин на плоских екстенсивних зелених дахах Львова;

- встановити систематичні, біоморфологічні, синтаксономічні та діаспорнохорні характеристики спонтанних видів;

- встановити залежність між типом озеленення даху та видовим складом спонтанних рослин, а також можливі шляхи та способи поширення їх діаспор;

- запропонувати заходи задля утримання видового складу культивованих видів та композиційної структури плоских зелених дахів.

Наукова новизна отриманих результатів дослідження - вперше розроблено методику, яка дає змогу дослідити спонтанні види рослин на зелених дахах і простежено шляхи їх занесення. Традиційно вважалося, що бур'яни заносяться із субстратом, для чого виконували дороговартісні заходи для його стерилізації. Наші дослідження показали, що спонтанні види потрапляють на зелені дахи різними шляхами.

Практична значущість результатів дослідження вони дають змогу правильно обрати вид озеленення й істотно вдосконалити агротехніку утримання зелених дахів, зменшити витрати на їх влаштування та догляд за насадженнями.

Аналіз останніх досліджень та публікацій. Огляд вітчизняної і зарубіжної літератури засвідчив, що у термін "зелений дах" дослідники та практики з різноманітних спеціальностей вкладають різну суть. Будівельники та спеціалісти архітектурно-планувальних рішень садів на дахах класифікують їх за типами будівель, на яких вони створені, і зводять до кількох основних типів: а) трав'яні дахи в малоповерховому будівництві; б) сади на терасах; в) сади на дахах прибудов; г) сади на дахах багатоповерхових будівель для використання як дитячих садків, для спорту та офісів. Сучасна архітектурна типологія зелених дахів передбачає також їх класифікацію за призначенням і використанням (інтенсивним чи екстенсивним), розміщенням у структурі будівлі, характером мікроландшафту, переважанням будівельних матеріалів [13]. Натомість ландшафтні архітектори, озеленювачі і спеціалізовані ботаніки схильні класифікувати зелені дахи за видовим складом i, насамперед, за домінуванням життєвих форм рослин, використаних у озелененні. Тому вони виділяють трав'яні (газонні), сукулентні, деревно-кущові та змішані дахи, а також за специфікою використання рослин виокремлюють лікарські, овочеві, сади духмяних трав та безперервного цвітіння і навіть дахи для вирощування овочів і грибів [18]. Дослідження зелених дахів сьогодні здійснюють у різних напрямках. Найбільш вивченим є напрям конструктивного вирішення зелених покрівель $[9,11,12,20]$. Чисельні дослідження стосуються екологічних функцій $[5,16,19,23]$ та класифікації озеленених дахів $[12,13$, $18,19]$. Асортимент рослин для зеленого даху теж детально вивчено $[1,4,6,12,7,8,11,14,17]$. Останніми роками зелені дахи розглядають у ранзі ніш для збереження біорізноманіття [3, 4], у цій же площині знаходяться й наші дослідження. 32010 р. технології озеле- нення дахів у Львові 3 використанням професійних субстратів, газонних сумішей та асортименту рослин впроваджує німецька компанія "ZinCo $\mathrm{GmbH}$ ", офiційним представником якої є "ZinCo Ukraine" [12]. Проте, незважаючи на широке зацікавлення темою озеленення покрівель, спеціальних досліджень щодо видового складу заносних видів, способів спонтанного поселення рослин та питань забур'янення зелених дахів досі не було.

Матеріали та методи дослідження. Дослідження видового складу рослин плоских зелених дахів в умовах Львова здійснювали впродовж 2016-2020 рр. методом облікових ділянок. Об'єкти для досліджень обирали однотипні, створені за єдиною технологією. Латинські назви судинних рослин і мохоподібних наведено за: The Plant List [24]. Синтаксономічну приналежність видів визначали у координатах еколого-флористичної класифікації рослинності і методу J Braun-Blanquet [2]. Назви синтаксонів подано за W. Matuszkiewicz [15]. Кількісні та якісні характеристики видів визначали на основі класичних шкал $[10,22,21]$.

\section{Результати дослідження та їх обговорення}

На сьогодні у Львові відомо понад 20 об'єктів приватної та державної власності, на яких влаштовано озеленені дахи на різних висотах. Їх експлуатація відбувається 3 мінімальним доглядом за рослинами 1-2 рази на рік, що є важливим чинником формування спонтанної флори. Упродовж 2016-2020 рр. проведено дослідження видового складу рослин на плоских зелених дахах в умовах Львова. Досліджено 18 об'єктів, на яких проведено повний облік видового складу культивованих та спонтанних видів рослин та зафіксовано кількісні та якісні характеристики культурфітоценозів. Досліджено структуру спонтанної ценофлори, яка супроводжує культурфітоценози зелених дахів. Виокремлено групи зелених дахів за типом озеленення та домінуючою біоморфою культивованих видів рослин.

Досліджені ділянки зелених дахів належать до плоских - екстенсивних та дахів із навантаженням мінімальної інтенсивності. Параметри таких дахів мають багато спільного, оскільки створені з використанням однакових пакетів та субстратів, різниця полягала у підборі рослин і товщині субстрату для конкретних типів дахів [2]. Оскільки досліджені дахи розміщені у житловій забудові Львова, використання добрив, отрутохімікатів та гербіцидів було строго лімітоване, тому поява бур'янних видів на таких дахах стала закономірним явищем. Виокремлено групи екстенсивних зелених дахів за типом озеленення та асортиментом використаних видів рослин. До досліджень залучено чотири найпоширеніші в умовах Львова типи дахів: 3 перевагою сукулентних рослин ("Седумний килим"), газонний дах, дах середземноморського типу із ефіроносних рослин ("Духмяні трави") і дах з використанням деревних рослин ("Сад на даху"). На багатьох об'єктах можна було спостерігати і поєднання всіх чотирьох типів, у такому разі облік видового складу проводили на окремих ділянках, які були виділені на основі домінантної біоморфи.

Як рекомендує компанія "ZinCo Ukraine", в умовах міського середовища однією із найдоцільніших для використання на плоских дахах є система "Седумний килим", яка і створена у багатьох місцях Львова. Вона використовується там, де, окрім невеликої ваги, потрібні 
мінімальні витрати на обслуговування. Параметри такої системи є мінімальними: висота 9 см, субстрат 6-12 cм,

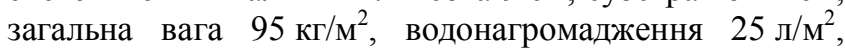
співвідношення стоку C: 0,34 [12]. У композиціях сукулентних дахів ми виявили такі види та їх культивари, як: Phedimus selskianus (Regel \& Maack) 't Hart. 'Spirit', Pistorinia hispanica (L.) DC., Sedum aizoon L. 'Euphorbioides', Sedum acre L. 'Aureum', Sedum album L. 'Coral Carpet', Sedum hybridum L., Sedum kamtschaticum Fisch., Sedum rupestre L. 'Angelina', Sedum spurium M. Bieb., S. s. 'Roseum', S. s. 'Purpur Winter', Sedum spectabile Boreau, S. s. 'Brilliant'. Більш рідкісними є посадки в таких композиціях Sedum alpestre Vill., Sedum ewersii Ledeb., Sedum forsterianum $\mathrm{Sm}$.

Зелений дах системи "Духмяні трави" дає змогу при невеликій висоті субстрату висаджувати багаторічні трави і напівкущі. Параметри такого типу даху є потужнішими: висота 16 см, загальна вага 180 кг $/ \mathrm{m}^{2}$, водонагромадження 68 л/м², співвідношення стоку C: $<30$ [12]. На дахах $з$ використанням ефіроносних рослин відзначено Anaphalis triplinervis (Sims) Sims ex C. B. Clarke 'Sommerschnee', Clinopodium nepeta (L.) Kuntze, Geranium macrorrhizum L. 'Spessart', Hyssopus officinalis L., Lavandula angustifolia Mill., Matricaria breviradiata (Ledeb.) Rauschert, Nepeta $\times$ faasenii Bergmans ex Stearn, Origanum majorana L., Origanum vulgare L. 'Compacta', Phuopsis stylosa (Trin.) Hook.f. ex B. D. Jacks. 'Purpurea', Santolina chamaecyparissus L., Waldsteinia ternata (Stephan) Fritsch.

Система озеленення з використанням газонів використовується переважно на підземних паркінгах чи перекриттях технічних будівель. Параметри цієї системи: висота $23 \mathrm{~cm}$, субстрат $10 \mathrm{~cm}$, загальна вага $305 \mathrm{\kappa г} / \mathrm{m}^{2}$, водонагромадження 100 л/ ${ }^{2}$, співвідношення стоку не визначено [12]. Газони створюють із суміші Festuca rubra L., Lolium perenne L., Poa pratensis L. Зрідка доповнюють їх також солітерними посадками інших злаків - Calamagrostis epigejos (L.) Roth, Miscanthus sinensis Andersson, Festuca glauca Vill., F. amethystina L., створюючи сад злаків.

Конструктивно найскладнішим $є$ дах 3 потужним шаром субстрату, в озелененні якого використано деревні види. Параметри цієї системи: висота $27 \mathrm{~cm}$, субстрат 20-40 см, загальна вага 340 кг/м², водонагромадження 110 л/м², співвідношення стоку не визначено [12]. У таких посадках у межах Львова 3 деревних рослин ми виявили Berberis thunbergii DC. 'Atropurpurea', B. th. 'Halmond Pillar', Buxus sempervirens L., Catalpa bignonioides Walt. 'Nana', Chamaecyparis pisifera (Siebold \& Zucc.) Endl., Cornus mas L., Cotoneaster horizontalis Decne, Euonymus fortunei (Turcz.) Hand.-Mazz., Hydrangea arborescens L. 'Annabelle', Juniperus virginiana L., Juniperus squamata Buch.-Ham. ex D. Don 'Blue Carpet', Juniperus $\times$ media V. D. Dmitriev, Juniperus scopulorum Sarg., Juniperus sabina (Aiton) A. E. Murray 'Tamariscifolia', Physocarpus opulifolius Schuch 'Luteus' (hort. ex Petz. \& G. Kirchn.) Zabel, Picea glauca (Moench) Voss. 'Conica', Picea omorika (Pancic) Purk. 'Nana', Pinus mugo Turra 'Mops', P. m. 'Pumilio', Spiraea japonica Desv., Potentilla fruticosa L., Schizandra sinensis (Turcz.) Baill., Taxus baccata L., Tsuga canadensis (L.) Carrière та ін.

За результатами виконаних досліджень встановлено, що незважаючи на абсолютно різне технічне й архітектурне вирішення проектів, різний асортимент рослин, використаних для створення зелених дахів, комплекс спонтанних видів формується 3 певною закономірністю. На ділянках озеленення плоских дахів Львова, окрім культивованих видів, виявлено 57 видів судинних рослин і 2 види мохоподібних, які поселилися спонтанно. Аналіз видового складу угруповань та облік бур'янів за окремими типами дахів засвідчили, що їх поселення має не стихійний характер. Спонтанну флору зелених дахів складають 59 видів вищих рослин, які належать до 19 родин. Найчисельнішими є родини Asteraceae (15 видів), Poaceae (6 видів), Brassicaceae і Polygonaceae (по 5 видів), Scrophulariaceae (4 види), Rosaceae (3 види). Решта родин мають по 1-2 види.

Видовий склад спонтанних видів у розподілі за типами зелених дахів має такий вигляд (де: C - "Седумний килим", Г - "Газонний дах", Т - "Духмяні трави", Д - "Сад на даху"): Achillea millefolium L. (C, Г, Д), Agrostis stolonifera L. (C, Г, Д), Ajuga reptans L. (C, Д), Alchemilla incisa Buser $(\mathrm{C}, \Gamma)$, Anagallis arvensis L. (Г), Arabidopsis arenosa (L.) Lawalrée.(C, Д), Artemisia vulgaris L. (C, Д), Bellis perennis L. (C, Г, Д), Berteroa incana (L.) DC. (C, Д), Bidens frondosa L. (C, Г, Д), Bromus hordeaceus L. (C, Г), Bryum argenteum Hedw. (C, Г, Т, Д), Bryum caespitosum (Hoppe \& Hornsch.) Brid. (C, Г, T, Д), Capsella bursa-pastoris (L.) Medik. (C, Т, Д), Cardamine hirsuta L. (C, Д), Chelidonium majus L. (C, Д), Chenopodium albumL. (C, T, Д), Chenopodium rubrum L. (C, Д), Descurainia sophia (L.) Webb ex Prantl (C), Echinochloa crus-galli (L.) P. Beauv. (C, T, Д), Elymus repens (L.) Gould $(\mathrm{C}, \Gamma, \mathrm{T}$, Д), Erigeron canadensis L. (C, Г, Т, Д), Euphorbia helioscopia L. (C), Hypochaeris glabra L. (C, Г, Д), Lapsana communis L. (C, Д), Linaria vulgaris Mill. (C, T, Д), Lysimachia nummularia L. (Д), Matricaria chamomilla L. (Г), Oxalis corniculata L.(C, T, Д), Oxalis stricta L. (C, Д), Pastinaca sativa L. (C, Г, Д), Pennisetum glaucum (L.) R. Br. (C, Г, Д), Persicaria maculosa Gray (Г), Plantago lanceolata L. (Т, Д), Plantago major L. (C, Г, Т, Д), Poa annua L. (C, $\Gamma$, Д), Polygonum aviculare $\mathrm{L} .(\Gamma, \mathrm{T})$, Polygonum dumetorum L. (Г), Portulaca oleracea L. (C), Potentilla anserine L. ( $\Gamma)$, Potentilla reptans L. (C), Prunella vulgaris L. (C), Ranunculus repens L. ( $\Gamma$, Д), Ranunculus acris L. (C, Г, Д), Rumex confertus Willd. (C), Rumex crispus L. (C), Senecio viscosus L. (C), Senecio vulgaris L. (C, Д), Silene latifolia Poir. (C), Sonchus oleraceus (L.) L. (C), Sonchus arvensis L. (С, Г, Д), Stellaria media (L.) Vill. ( $Г, ~ T)$, Stenactis annua (L.) Cass. (С, Г, Д), Taraxacum campylodes $\mathrm{G}$. E. Haglund (C, Г, Д), Trifolium repens L. (C), Tussilago farfara L. (C, Д), Verbascum nigrum L. (Д), Veronica filiformis Sm. (Г, Д), Veronica persica Poir. (С, Г, Т, Д). Тільки шість видів спонтанної ценофлори трапляються на всіх типах зелених дахів, не виказуючи прив'язаності до культурценозу та агротехніки. На трьох типах дахів (окрім "Духмяних трав") поселяється 12 видів, а на інших трьох (окрім газонного) 5 видів. Стенотопністю відзначаються види, які ростуть тільки на "Седумному килимі" - їх 11, тільки на газонному даху трапляється 5 видів, в "Саду на даху" -2 .

У синтаксономічному вимірі спонтанні види розподілені поміж 7 класами рослинності, виділеними за методикою J. Braun-Blanquet [2]. Більшість виявлених видів належать до класу Molinio-arrhenatheretea R. Tx. 1937 порядку Plantaginetalia majoris R. Tx. (1943) 1950 союзу Poligonion avicularis Br.-Bl. 1931 ex Aich. 1933 а також порядку Trifolio fragiferae-Agrostietalia 
stoloniferae R. Tx. 1970 союзу Agropyro-Rumicion crispi Nordh. 1940 em. R. Tx. 1950. Велику групу складають сегетальні види класу Stellarietea mediae R. Tx., Lohm. et Prsg, 1950 порядку Sisymbrietalia J. Tx. 1961 союзу Sisymbrion officinalis R. Tх., Lohm., Prsg. 1950 (рисунок).

У біоморфологічному вимірі основу спонтанної ценофлори становлять багаторічні рослини (47 \%). Другу за чисельністю групу складають однорічні види (41\%). Дворічники охоплюють всього 12 \% видів. Згідно $з$ класифікацією I. Серебрякова [18] у дослідженій множині спонтанних видів переважають стрижнекореневі (56 \%) види. Помітну групу (17\%) становлять також довго- i короткокореневищні види.
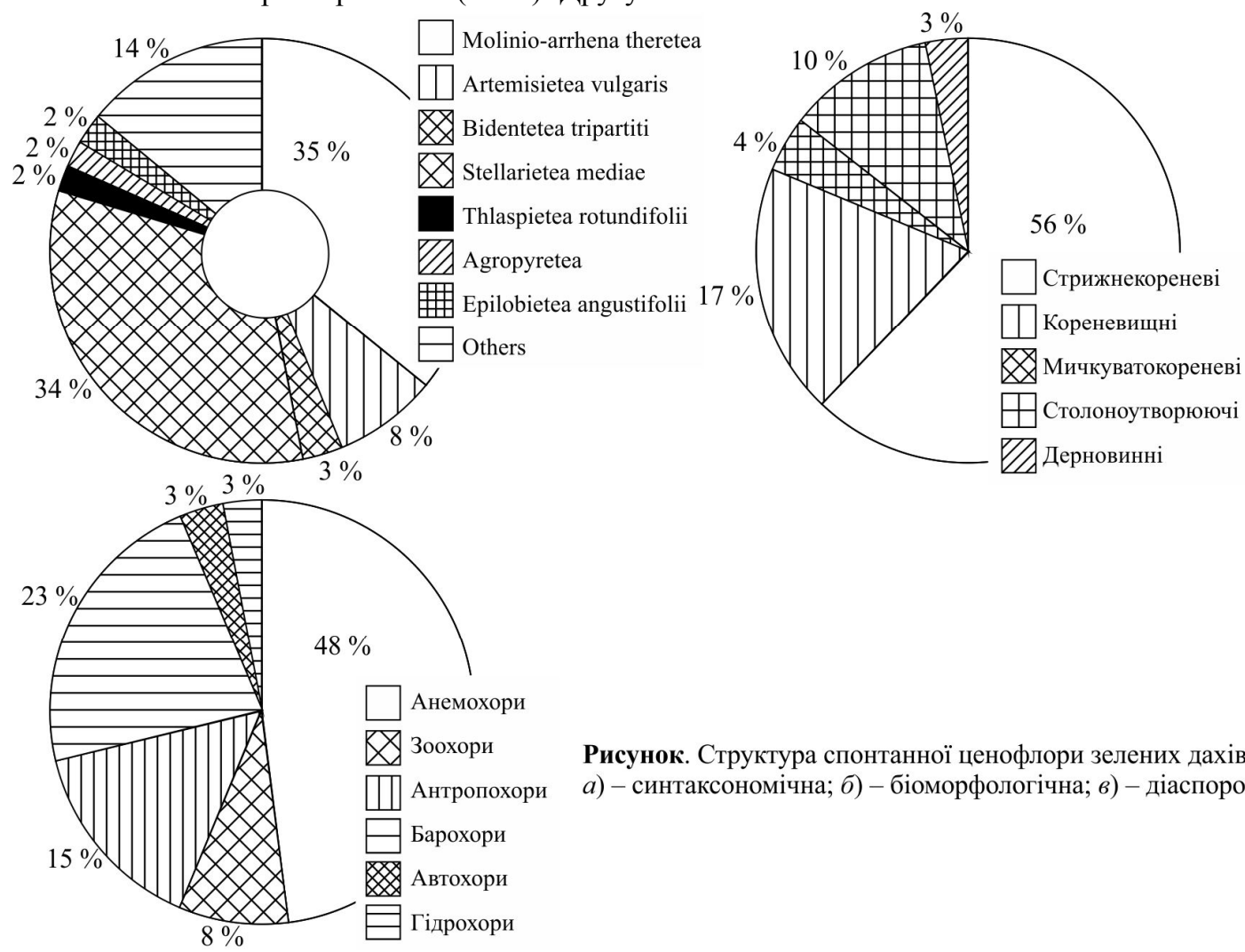

Рисунок. Структура спонтанної ценофлори зелених дахів: a) - синтаксономічна; б ) - біоморфологічна; $в$ ) - діаспорохорна

Структура клімаморф за С. Raunkiaer [21] повністю відповідає біоморфологічній структурі. Домінантною морфою є гемікріптофіти (59 \%), їм дещо поступаються терофіти (41\%). Серед діаспорохорів переважають анемохори (48 \%), великі групи складають барохори (23\%) i антропохори (15\%), що яскраво ілюструє способи занесення діаспор на озеленені дахи.

\section{Висновки}

Отже, внаслідок проведеного дослідження було виявлено видовий склад та здійснено флористичний аналіз спонтанної ценофлори на плоских зелених дахах екстенсивного типу в умовах Львова, що дало змогу запропонувати заходи задля утримання видового складу культивованих видів і композиційної структури плоских зелених дахів. За результатами дослідження можна зробити такі основні висновки:

1. За однакових умов спонтанні види рослин поселяються залежно від типу озеленення даху, тому тип використаного озеленення істотно впливає на формування подальшого фітоценозу та визначає основні напрями агротехніки утримання зелених насаджень екстенсивного даху.

2. Серед досліджених видів із спонтанним поселенням переважають стрижнекореневі анемохоричні гемікриптофіти рудерального і сегетального флороценокомплексів, що відповідає початковому етапу заростання порушених земель.

3. Вважалося, що найімовірнішим шляхом розселення бур'янів на зелених дахах є занесення із субстратом,

проте високоякісна підготовка грунту та його стерилізація і використання композитних матеріалів унеможливлюють цей процес. Наші дослідження довели, що більшість видів потрапляє на дахи анемохоричним шляхом, і тільки невелику частину заносить людина під час догляду насаджень.

\section{References}

1. Blanusa, T., Monteiro, M. M. V., Fantozzi, F., et al. (2013). Alternatives to Sedum on green roofs: Can broad leaf perennial plants offer better cooling service?. Building and Environment, 59, 99-106.

2. Braun-Blanquet, J. (1964). Pflanzensoziologie. Grundzuge der Vegetationskunde. Wien-New York: Springer. [In Deutsch].

3. Brenneisen, S. (2006). Space for urban wildlife: designing green roofs as habitats in Switzerland. Urban habitats, 4, 27-36.

4. Butler, C., Butler, E., \& Orians, C. M. (2012). Native plant enthusiasm reaches new heights: Perceptions, evidence, and the future of green roofs. Urban forestry \& urban greening, 11(1), 1-10.

5. Castleton, H. F., Stovin, V., Beck, S. B., \& Davison, J. B. (2010). Green roofs; building energy savings and the potential for retrofit. Energy and buildings, 42(10), 1582-1591.

6. Diachenko, A. D., \& Klimenko, A. V. (2013). Perspektivnyi assortiment rastenii dlia ispolzovaniia na kryshakh podzemnykh sooruzhenii. Scientific Bulletin of UNFU, 23(5), 219-225. [In Russian].

7. Dunnett, N., \& Kingsbury, N. (2004). Planting Green Roofs and Living Walls. Portland: Timber Press, $320 \mathrm{p}$.

8. Hrytsenko, V. V. (2012), Problems of adventization of steppe cultural phytocoenosis. Sinantropization of plant cover in Ukraine: Abst. of Conf. Kyiv; Pereyaslav Khmelnytskyi, pp. 24-26.

9. Forman, R. T. (2014). Urban ecology: science of cities. Cambridge University Press, $246 \mathrm{p}$. 
10. Fukarek, F. (1967). Fitosocjologia. Warszawa: PWR i L, 420 p [In Polish].

11. Getter, K. L., \& Rowe, D. B. (2006). The role of extensive green roofs in sustainable development. HortScience, 41(5), 1276-1285.

12. Katalog standartnykh reshenii ZinCo. (2016). Rukovodstvo dlia proektirovaniia. Retrieved from: http://zincocatalogue.mystrikingly.com/\#gallery_2-16. [In Russian].

13. Krainykovets, O. V., Didyk, V. V., \& Maksymiuk, T. M. (2012). Sady na dakhakh. Arkhitektura, 728, 119-125. [In Ukrainian].

14. Macivor, J. S., \& Lundholm, J. (2011). Performance evaluation of native plants suited to extensive green roof conditions in a maritime climate. Ecological Engineering, 37(3), 407-417.

15. Matuszkiewicz, W. (2001). Przewodnik do oznaczania zbiorowisk roślinnych Polski. Warszawa: Publishing PWN. [In Polish].

16. Melnychuk, I. V. (2008). Pro napriamy enerhozberezhennia v zhytlovomu fondi. Ekonomichnyi prostir, 12(2), 164-170. [In Ukrainian].

17. Nagase, A., \& Dunnett, N. (2010). Drought tolerance in different vegetation types for extensive green roofs: effects of watering and diversity. Landscape and urban planning, 97(4), 318-327.
18. Novoselchuk, N. Ye. (2008). Do pytannia klasyfikatsii dakhu, shcho ekspluatuietsia. Visnyk Kharkivskoi derzhavnoi akademii dyzainu i mystetstv, 3(5), 99-105. [In Ukrainian].

19. Oberndorfer, E., Lundholm, J., Bass, B., et al. (2007). Green roofs as urban ecosystems: ecological structures, functions, and services. BioScience, 57(10), 823-833. https://doi.org/10.1641/B571005

20. Osmundson, T. (1979). The changing technique of roof garden design. Landscape Architecture, 69(5), 494-503.

21. Raunkiaer, C. (1934). The life forms of plants and statistical plant geography. Oxford: Clarendon Press, 262 p.

22. Serebriakov, I. G. (1962). Ekologicheskaia morfologiia rastenii: Zhiznennye formy pokrytosemennykh i khvoinykh. uchebn. posobie. Moscow: Graduate School, 378 p. [In Russian].

23. Susca, T., Gaffin, S. R., \& DellOsso, G. R. (2011). Positive effects of vegetation: Urban heat island and green roofs. Environmental pollution, 159(8-9), 2119-2126.

24. The Plant List. (2020). A working list of all plant species. Retrieved from: http://www.theplantlist.org

O. Ye. Halevych, M. I. Soroka

National University of Forestry Engineering Lviv, Ukraine

\section{ANALYSIS OF SPONTANEOUS FLORA ON THE FLAT GREEN ROOFS OF EXTENSIVE TYPE IN LVIV CITY}

In the city of Lviv, there are 18 researched objects with green flat roofs of extensive type situated on the different heights and different building types. In the course of research some modern methods and technologies of creating green roofs are analysed and the basic directions of exploration in this branch are highlighted. The basic principles of classification and typification of green roofs are considered. An inventory of the species composition of cultivated and spontaneous plant species was made. The groups of green roofs were singled out according to the used species of the dominant biomorph. They were devided into the following types: with a predominance of succulents; lawn roofs; with the participation of essential plants of the Mediterranean flora; with the use of woody plants. For the first time in works of this type the spontaneous cenoflora which accompanies cultural phytocenoses of green roofs is investigated. It is established that the type of landscaping significantly affects the formation of the phytocenosis and determines the main directions of agricultural techniques for the maintenance of extensive roof plantations. It was revealed that there was a close dependence between the type of roof landscaping and the kind of variety of spontaneous plants. Some ways of spreading diasporas of listed species are also defined. The floristic analysis of the spontaneous cenoflora of flat green roofs showed that it consisted of 59 species, more of them are ruderal weeds, which originate from the syntaxonomic class MOLINIO-ARRHENATHERETEA. The second largest group consists of segetal weeds which originate from the class STELLARIETEA MEDIAE. It evidences about a high agricultural techniques of keeping plant compositions on the roofs, where spontaneous species of the first stage of overgrowth of the processed prevail. There were taproot polycarpic anemochoric hemicryptophytes between the identified species of weeds, that characterizes the method of their inclusion in plant compositions. The majority of the studied species were not planted with the substrate, but later they settled due to diaspora by wind. The numerical groups consist of species-barochors and anthropochors, which are setteled in the process of agricultural work. Although listed plant species make negative influence on the artistic and aesthetic, decorative and ecological function of roof landscaping. For the first time, the effectiveness and feasibility of the proposed research in this destination was proved. It was necessary to improve agrotechnical methods in order to maintain the species composition of plant compositions and to implement effective environmentally safe measures for preventing weeding of plant compositions of green roofs.

Keywords: roof landscaping systems; weeds; cultivated species; cultivars. 